\title{
'And They Sleep Together Like Husband and Wife': A Queer Queensland Genealogy
}

\author{
Belinda McKay
}

The emergence of modern queer identities is usually located in cities - initially the European and American metropolises, followed by provincial or colonial cities like Sydney. While the argument that a critical mass of people triggers the formation of new identities is compelling, a centralised, urban model of the generation of modern queer identities ignores an alternative theoretical model emphasising flow and connection between the 'centre' and the 'margins' that has emerged in writing about colonial and post-colonial cultures, but which has a wider applicability in understanding cultural change. ${ }^{1}$ In this paper, I argue that marginalised same-sex behaviours and relationships on the periphery of the empire or the nation are implicated in larger patterns of interconnectedness and reciprocity in the historical formation of modern sexual identities. ${ }^{2}$ Specifically, I use a family study to explore manifestations of same-sex attraction in early twentieth century Cooktown and the influence of these sexual role models on three subsequent generations.

Inevitably, my exploration of the private lives of people who are not on the public record is speculative, but no more so than any biography. As Martha Vicinus has argued: 'Discontinuity and reticence do not mean silence or absence. Many lesbian histories, contradictory, complicated, and perhaps uncomfortable, can be told.'3 Here I use oral histories, letters and photographs, together with public records, to piece together the queer history of my family and place it in the broader context of the emergence of contemporary queer identities. My genealogical focus does not imply a position on the essentialist versus constructionist debate: although many members of my family (from a range of sexual identities) insist that a 'gay gene' must be at work, I am more interested in this paper in a genealogy of nurture than of nature.

\section{Growing Up on the Northern Frontier: Carlton and Gladys Olive}

Carlton Olive (1881-1958) and his sister Gladys Olive (1894-1965) of Cooktown were certainly 'queer' according to the ordinary sense of their own era - 'strange, odd, peculiar, eccentric' (OED). To the self-identified gay and lesbian members 
(including myself) of three subsequent generations of their family, Carlton and Gladys were also 'queer' in the subcultural usage of their era, which has become the dominant modern sense of the word, viz. non-heteronormative. Although it is not possible to know precisely how Carlton and Gladys thought of their own sexuality, or to discover the specific nature of their sexual practices, they clearly organised their private lives to give expression to desires considered deviant, pathological and sometimes even criminal in their time. In this paper, I use the descriptor 'queer' suggestively rather than prescriptively, embracing its ambiguity, in my exploration of non-normative interactions of gender, sex and desire. As David Halperin observes, 'queer' is not a synonym for terms like 'gay' or 'lesbian', although it might include them: 'queer is by definition whatever is at odds with the normal, the legitimate, the dominant'. ${ }^{4}$

Carlton Chaloner Olive, known to intimates as 'Bando' (pronounced 'Barndoe'), was born in Cooktown on 13 August 1881, less than seven years after the town was established as the port for the Palmer River goldfields. Cooktown, still the northernmost town on the eastern coast of Cape York Peninsula, was in effect the toehold of white conquest in an area of Aboriginal resistance. During Carlton Olive's childhood in the 1880s, the town quickly built the infrastructure and institutions of a colonial outpost. Renowned as the 'Queen of the North' and the 'Canton of the South', Cooktown supported a substantial population of European and Chinese merchants, and its economic and cultural orientation was northward to New Guinea, Asia and beyond, as much or more than to Australia's emerging urban centres of Sydney and Melbourne. However, Cooktown's spectacular boom was brief: it was well and truly over by the time Gladys Olive - also known as Gladole - was born on 11 June 1894, the fourteenth of 15 children. ${ }^{5}$ To understand the later lives of these two individuals, it is critical to look at the milieu that shaped them.

Their parents, Edmund Abraham Cumberbatch Olive and his de facto wife Grace Neil arrived in Cooktown with their infant son Edmund in 1874 or 1875 , at the peak of the Palmer River gold rush (see Figures 1 and 2). ${ }^{6}$ In 1876, E.A.C. Olive established a business as an auctioneer, and horse and cattle salesman. Subsequently, he developed lucrative sidelines as a commission agent and general broker. He became a prominent citizen of early Cooktown, holding a variety of public positions including Shire Clerk, Cooktown Hospital Board Secretary, Returning Officer for the seat of Cook, and Captain of the Cooktown Garrison Battery.

The Olive children were educated by English tutors and governesses at Mount Olive, a sprawling wooden bungalow on a hill overlooking Cooktown (see Figure 3), until the depression of the 1890s, when the younger children — including Gladys - briefly attended the local primary school. As well as the Olives' own children (13 of whom survived to adulthood), the household included an Aboriginal child known as Nellie, who had been 'rescued' by Grace Neil during the frontier wars. The Olive children referred not only to Nellie, but also to the other Aboriginal children at Mount Olive, as their brothers and sisters. Carlton and Gladys's sister Emma (Olive) Hope surprised people in Mossman when her smartly dressed, well-spoken and literate black 'brother' Sammy Olive dined with her family in Mossman in the 1930s. ${ }^{7}$ 


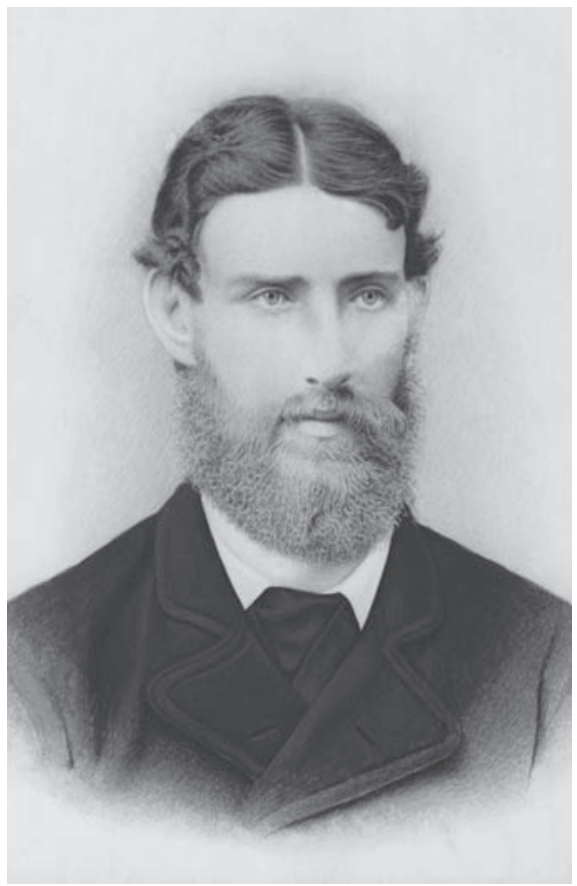

Figure 1: Edmund Abraham Chaloner Olive

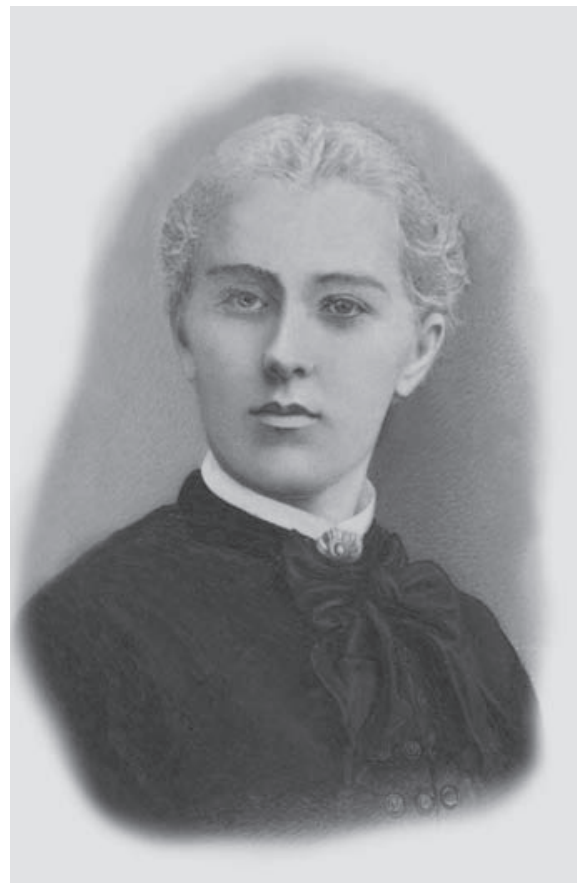

Figure 2: Grace (Neil) Olive

Exacting standards of discipline were imposed on the household by E.A.C. and Grace Olive, but the Olives were eccentric and non-conformist in other respects. E.A.C. Olive is said to have been the 'black sheep' of his English family, and to have come to Australia in disgrace - possibly following a sexual indiscretion. He and Grace Neil did not marry until 1876, when they had already had three children (the two surviving illegitimate children were legitimised in 1900). The most likely reason for the delayed marriage is that Grace Neil was unable to obtain her father's permission to marry and therefore was forced to wait until she turned 21, but stories circulated in Cooktown that E.A.C. Olive had cut a sovereign in half, and that he and Grace Neil each kept a piece as a symbol of their private vows.

E.A.C. Olive was a declared atheist who held rationalist beliefs about matters such as death, refusing to erect headstones in the cemetery for family members. In his dress, too, E.A.C. Olive was unconventional: perhaps in adherence to principles of the Rational Dress movement, he eschewed suits in favour of loose-fitting garb reminiscent of the informal dress of Cooktown's Chinese merchants (see Figure 4) In fact, he appears to have enjoyed unusually warm relations with the Chinese community and, according to his granddaughter Grace (Olive) Worrall, he spoke Chinese and interpreted for Customs. Grace (Neil) Olive — whose formal education was probably limited — ran the household: she gave birth to 15 children, kept bees, made all the bread, and spent a good deal of time on needlework. She was a strict domestic disciplinarian, and attended Church of England services, but seems to have played no role in public life. 


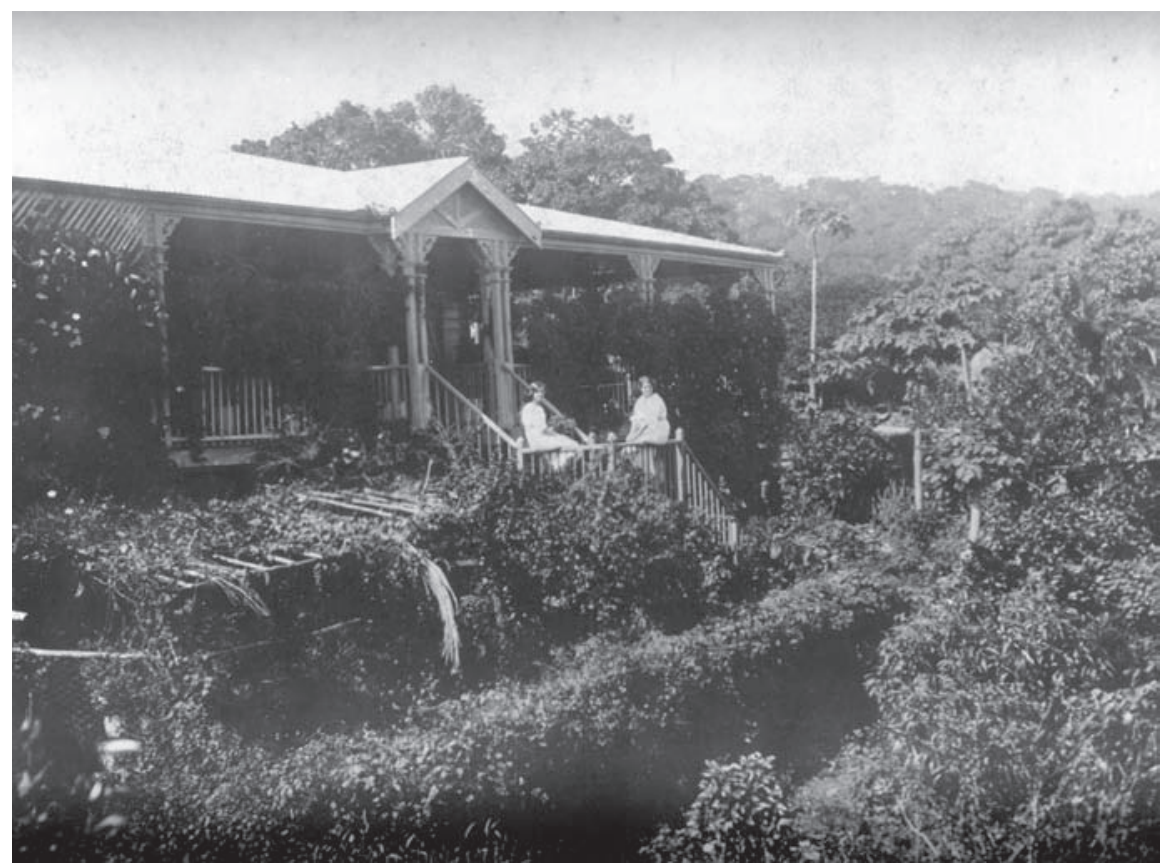

Figure 3: Mount Olive

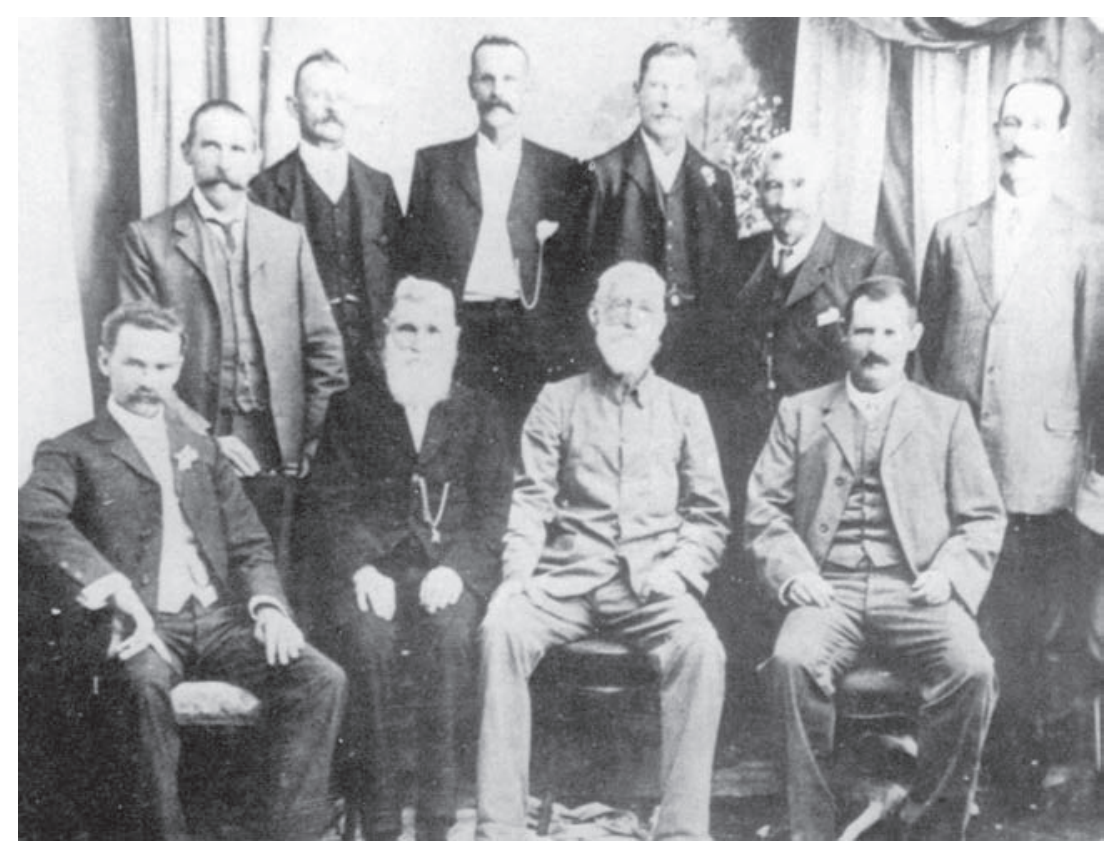

Figure 4: E.A.C. Olive (front, second from right) is the only member of the Cooktown Chamber of Commerce not wearing a suit in this photograph dated c. 1909. 
The Olive children enjoyed a high degree of freedom of movement and freedom from conventions, which applied to the girls as well as the boys. As his auctioneering business declined, E.A.C. Olive increasingly developed his interests in naturalism, with the assistance of local Aboriginal people. E.A.C. Olive's 'right-hand man', Billy Olive, and his son Sammy not only helped him to locate specimens, but also taught him and his children about bushcraft: in the words of Guinevere Sacre, a granddaughter of E.A.C. Olive, 'the blacks showed him everything'. ${ }^{8}$ All of the Olive sons sent specimens to the Australian Museum and private collectors, but family stories indicate that the Olive daughters also accompanied their father and the Aboriginal guides on some of the collecting expeditions. Eccentric and highly individualistic behaviour was appreciated and even encouraged within the family: for example, Carlton and Gladys's sister Grace once asked a pompous shop assistant for 'a jar of pickled mokens' - the word used in the family for penis. Similar stories of behaviour designed to shock outsiders are legion, and there was a prevailing attitude among family members that the opinion of others was of no account.

E.A.C. Olive was - paradoxically, even in his atheism - an exemplar of a post-Enlightenment Protestant ethic. On the maternal side, he descended from the Chaloners, prominent Protestant intellectuals during the English Reformation and Civil War, and the Carlton and Cumberbatch families, who were wealthy merchants and plantation owners in the West Indies. His father was an Oxford-educated vicar from a family of cloth dyers from Somerset, who had prospered during the Industrial Revolution and became prominent benefactors of the Church of England in Frome. E.A.C. Olive attended Marlborough College for the sons of the clergy under two headmasters who had taught at Rugby School under Dr Arnold. ${ }^{9}$ While his interest in the natural sciences, his atheism and his rationalism are markers of the influence on his thinking of Enlightenment values of freedom from religion and other superstition, the longer traditions that shaped him (and indeed those very Enlightenment values themselves) derived from the Protestant Reformation. E.A.C. Olive may have been a black sheep, but he reproduced in Australia the habits of mind and the family structures that had been successful for generations of his Protestant, capitalist forebears — and the naming of his children (e.g. Carlton Chaloner Olive) suggests that he consciously reinvoked these forebears in a new outpost of Empire. In both his eccentricity and his conventionality, E.A.C. Olive is an exemplar of the Protestant traits of internalisation of conscience, individuation and self-discipline.

The nature of the Olive marriage is central to understanding the lifestyles of their children. The formation of a binding but (initially) not legally or religiously sanctioned relationship between E.A.C. Olive and Grace Neil reveals that the inner authority of conscience took precedence over outward form. It was an extreme version (given Grace Neil's defiance of her father at the age of 16) of that notion of marriage as a voluntary union between free individuals that developed in Protestant England, and which has been identified by Ian Watt, among others, as a modernising force essential to the rise of capitalism. ${ }^{10}$ Janet R. Jakobsen points 
out further that the Reformation tied the very idea of individual freedom to the institution of marriage: 'The free individual is the individual whose sexual activity is regulated in marriage. ${ }^{, 11}$ The story of E.A.C. Olive cutting a sovereign to seal his union, even if apocryphal, is highly suggestive of the economic implications of such marriages, since this union was the precondition for the creation of a family economy that encompassed not only the numerous white children, but also the Aboriginal people who lived and worked at Mount Olive - and who, however problematically given the power imbalance, were always referred to by the Olives as family. Domestic life at Mount Olive exemplifies Durkheim's concept of the 'conjugal family', where the family is created by marriage and functions as an autonomous economic and social unit; the children individuate and separate themselves from their parents through their own marriages. Of the 13 Olive children who survived to adulthood, only Carlton and Gladys did not marry. Instead (as I will discuss in more detail later) they remained for some years in the family home along with a number of Aboriginal people in an anomalous family unit.

What non-conformist understandings of embodiment, gender and desire might emerge from an environment like Mount Olive in Cooktown? Eleven of the 13 Olive children who survived to adulthood married members of the opposite sex who were socially, economically and racially acceptable to the family and the wider Anglo-Australian society of the time. However, the fluidity of life in this outpost of Empire undermined stable and normative relations between embodiment, gender and desire. Within the family, the Protestant values of internalisation of conscience and individuation, filtered through Enlightenment rationalism, were highly valued. The Olive parents had themselves challenged the right of the law to interfere in relationships: they produced three children out of wedlock and may have participated in a symbolic ceremony of union.

Cooktown also offered other examples of the disruption of 'natural', normative or legally sanctioned expressions of desire. Barbara Baird has observed that interracial marriages 'surely remain at the troubling margins of normative marriage, even when certified by Australian law'. ${ }^{12}$ In nineteenth and early twentieth century Queensland, interracial marriage was prohibited in most cases, but long-term interracial relationships were, of course, not unknown. Traditional Aboriginal marriage ceremonies were generally not recognised by the white authorities, and Aboriginal people - along with Pacific Islanders, Malays, Chinese, Japanese and people of mixed race - were obliged to seek permission from white authorities to marry. Moreover, the ubiquitous presence in and around Cooktown of mixed-race children was also a marker of illicit desire. ${ }^{13}$ Mixed-race children were deprived of legal rights (as, technically, were the older Olive children until they were legitimised in 1900). Moreover, men vastly outnumbered women in Queensland at this time, and it was common for men to travel or live together without arousing comment. Carlton and Gladys's great-niece, Elizabeth Allan, has observed that, even in the 1940s and 1950s, life in North Queensland was more itinerant and organised in a much less heterosexual way than life in Brisbane: people dropped in to visit unexpectedly, and one did not have to have a ball partner or a dinner dance partner to participate in social life. ${ }^{14}$ 
Cooktown's sudden creation in the 1870s as a gold port, its involvement in the frontier wars, its multi-ethnicity, and its long decline into economic stagnation, meant that the codes of behaviour that prevailed by the late nineteenth century in Sydney, Melbourne and even Brisbane were at best only superficially and sporadically adopted. Cooktown was located on the boundary of effective colonial control, and Mount Olive itself is ambiguously located on the edge (just within the town boundary) of Cooktown. In 1885, just three years after the establishment of Mount Olive, the town passed a by-law banning Aboriginal people from being within its boundaries at night, a regulation which clearly represents only the surface level of hostility to Aborigines entering 'white' space. (The Mount Olive 'blacks' camp', remarkably, survived within the town boundary until at least the 1930s, and E.A.C. Olive also flouted local laws in allowing traditional ceremonies. $)^{15}$ It is possible that a preoccupation with the policing of race - for example, through the nightly expulsion of Aboriginal people, the prohibition on interracial marriages and the removal of 'troublemakers' to reserves like Palm Island — deflected some attention from gender and sexuality within the white community in Cooktown.

\section{Gender Bending}

The men who are sexually attracted by men have outward marks of effeminacy, just as women of a similar disposition to those of their own sex exhibit male characters.

\section{- Otto Weininger, Sex and Character (1907 [1903]) $)^{16}$}

In The Tin Scratchers, Ion L. Idriess describes how, when walking through the bush near Cooktown in 1912, he was startled by a rider who came up quietly behind him and then, with a yell, spurred on her horse:

I leapt aside right smart as a whirlwind galloped by throwing behind a peal of girlish laughter. With panting heart I swore at the vanishing horseman — a girl! Clad in pants with shirt-sleeves rolled up — I'd never seen a girl in pants before! Not those pants. Breathing heavily, I slouched back for the discarded swag, gazing after her flying through the timber. She took a log in her stride, an exultant yell as girl and horse leapt through the air. The devil of a rider! ...

Clatter of hooves away ahead, and a little mob of horses burst through the timber with a younger girl flying at their heels. The horses wheeled roguishly but, with a yell, my devil rider was at their flank driving them galloping all out for a big house up on the hill, a large bungalow set in a lovely garden of bamboos and shrubs and trees.

These were the Olive youngsters, rounding up the horses. What wonderful specimens of womanhood that team of girls of Olive the auctioneer was to grow into! ${ }^{17}$ 
The 'devil rider' was 16-year-old Gladys Olive and the younger girl her sister Doris. Idriess's confusion over Gladys's gender is understandable: even today, one has to look twice at the photograph of Gladys on the front cover of this issue of Queensland Review to be sure that she is a woman and not a man. Since the photograph considerably postdates Idriess's encounter with her, it seems reasonable to speculate from his account that Gladys was a 'mannish' woman from a very early age. According to a niece, Gladys 'wore pants long before anyone else did', and she excelled in 'manly' pursuits. She was a fine markswoman who, according to family members, could 'pick the eye out of a chook at 100 yards off the back of a horse' ${ }^{18}$ Early sexologists sustained that there was strong link between a 'mannish' appearance and 'sexual inversion' in women. Even today, most historians of sexuality would probably agree that Gladys's dress and behaviour were at least 'lesbian-like'. Idriess's account certainly indicates that Gladys disrupted normative gender codes, although he is quick to damp down the possibilities, ending this passage with a normalising comment that seems quite out of place: 'What wonderful specimens of womanhood that team of girls of Olive the auctioneer was to grow into!'

Carlton, in contrast to his mannish younger sister, was tall but slightly built and had a manner which could hardly fail to have been read - in an outpost like Cooktown no less than in the metropolis - as 'effeminate'. In a photo taken when he was already well into his thirties (see Figure 5) he is willowy, tanned and extraordinarily youthful - an eternal ephebe in the Dorian Gray mode. The image recalls Foucault's observation that, after the invention of the scientia sexualis in the nineteenth century, the sexuality of the homosexual became 'written immodestly on his face and body because it was a secret that always gave itself away' ${ }^{19}$ There is a suggestive similarity between Carlton's pose and that of Cecil Beaton in a photo taken at the races in the 1920s and used by Hugh David in On Queer Street: A Social History of British Homosexuality 1895-1995. ${ }^{20}$ Carlton's unusual (at least in the Cooktown context) affect is also remarked upon by an independent observer, British travel writer Barbara Toy, who described Carlton in later years as 'a very thin old man with a gentle manner'. ${ }^{21}$

Oscar Wilde's trial occurred in 1895, when Carlton was 14 and male homosexual activity was an actively prosecuted criminal offence in Queensland. In the late nineteenth century, the first wave of books on sexology, most notably Richard von Krafft-Ebing's Pyschopathia Sexualis (1886), had pathologised 'homosexuality' or 'inversion', characterising it as abnormal, and as a manifestation of degeneracy and even criminality. Such ideas quickly entered the popular domain, although by the early twentieth century new approaches were emerging among sexologists. In later editions of Sexual Inversion (originally published in 1897), Havelock Ellis notes the change from treating 'inversion' as a 'loathsome and nameless vice, only to be touched with a pair of tongs, rapidly and with precautions' to 'a psychological and medicolegal problem so full of interest that we need not fear to face it, and so full of grave social actuality that we are bound to face it'. His case studies, like those of Magnus Hirschfeld, revealed that a large percentage of 'inverts' were 'self-approving' and 'regard their feelings as natural'.22 


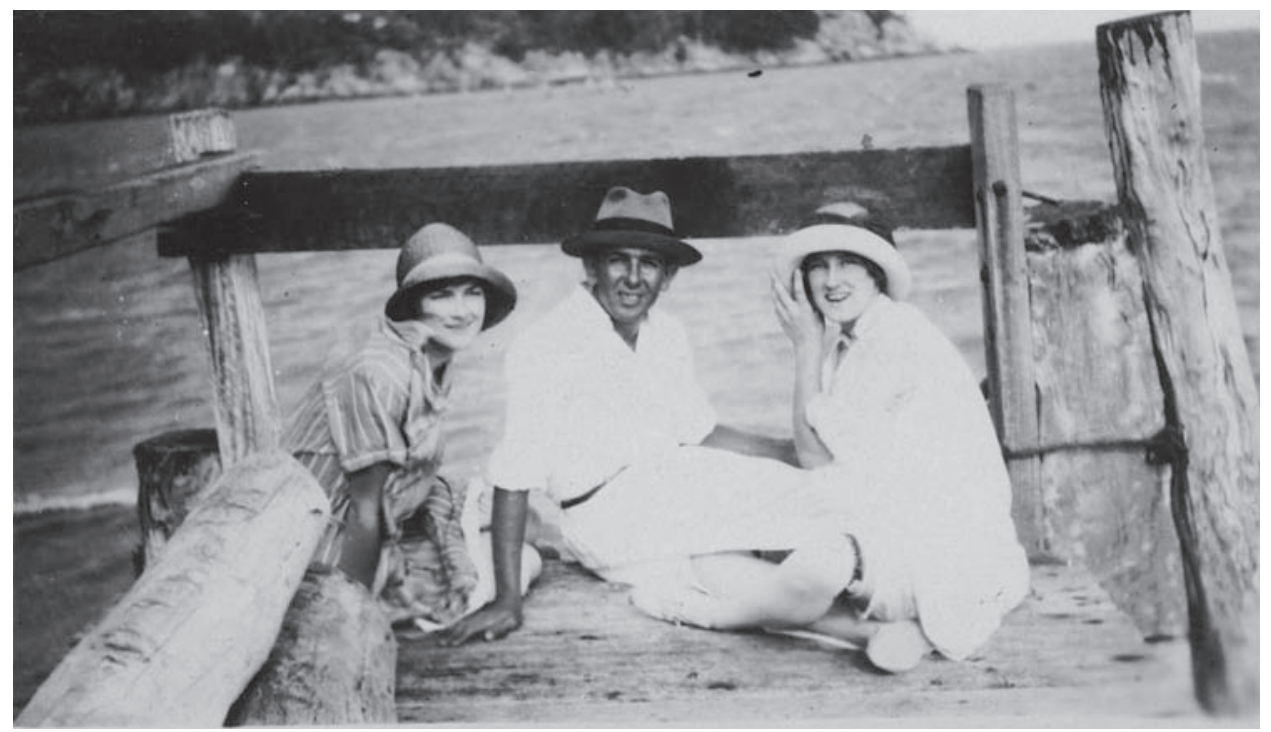

Figure 5: Carlton Olive with his nieces Grace Norbury (L) and Gladys Norbury (R), in Cooktown, c. 1920

Carlton Olive may have regulated his sexual behaviour to avoid prosecution, but in oral histories and photographs he emerges as a confident man, apparently untroubled by fears of suffering from a pathological condition. Moore and Jamison in this issue have discussed the emergence of the modern Australian male homosexual, identifying a transitional period in the twentieth century when the legal system — following the work of the new sexologists — began to treat homosexuality with less severity. The reorganisation of erotic categories, they argue, allowed men to be homosexual 'while maintaining normative behaviour patterns'. ${ }^{23}$ As well as working as an auctioneer and commission agent, and undertaking various community roles in Cooktown, Carlton Olive keenly pursued the 'masculine' activities of hunting, fishing and collecting natural history specimens, often in the company of Billy and Sammy Olive. Many photographs show him as a crocodile hunter (see Figures 6 and 7), and his prowess in these 'masculine' areas may have deflected some attention from questions about his sexuality. Although it is possible that he read the work of sexologists, his self-assurance probably derived mainly from the values of individuation and internalisation of conscience instilled into him within the family. These values produced in the Olives a manner that was sometimes interpreted by outsiders as arrogance, but they certainly seem to have protected Carlton, as well as Gladys and other 'queer' members of the family, from the 'fear of public opinion that hangs above [inverts] like the sword of Damocles' (to quote the words of an American correspondent of Havelock Ellis). ${ }^{24}$ 


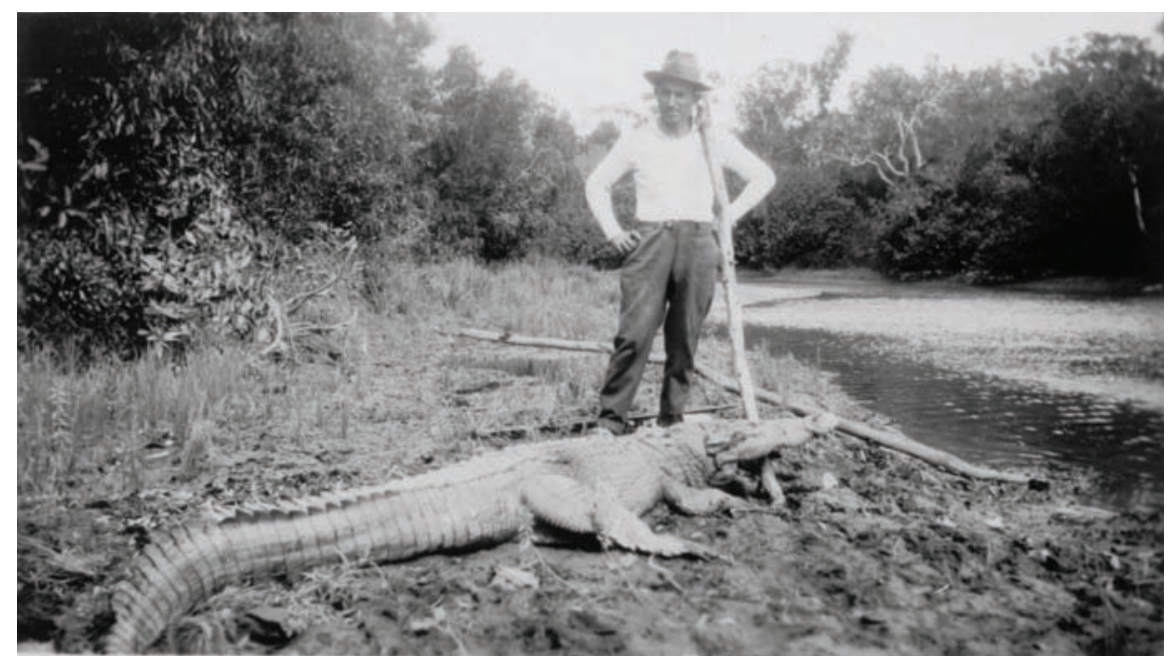

Figure 6: Carlton Olive as crocodile hunter, Cooktown, c. 1930

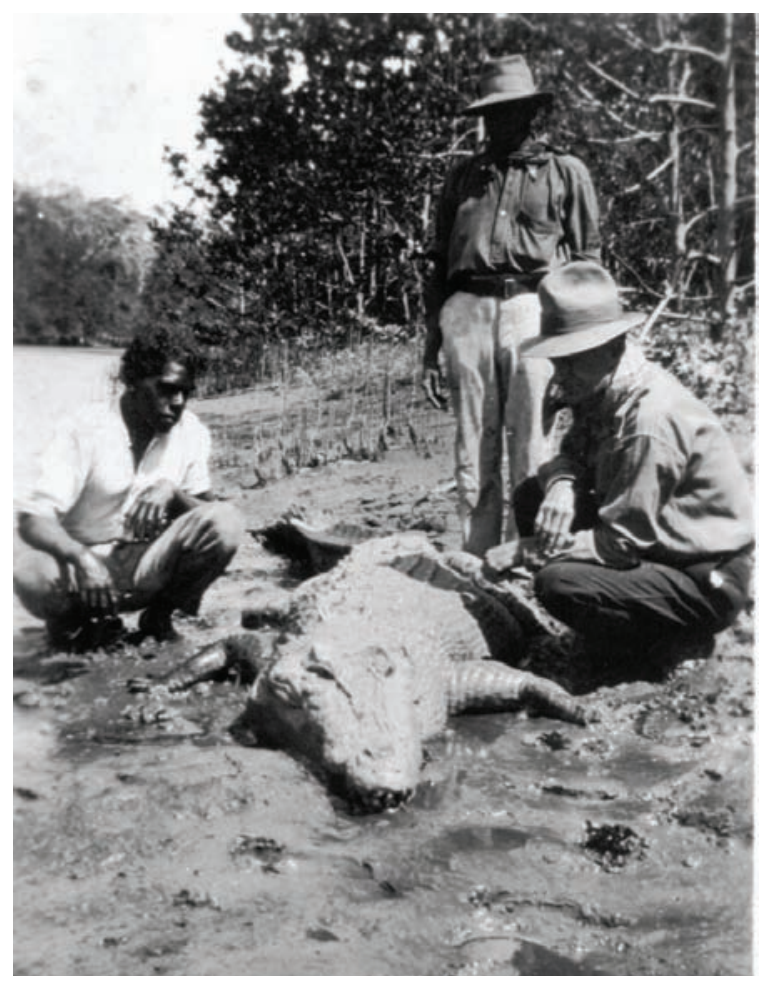

Figure 7: From left, Sammy, Billy and Carlton Olive survey their prize, c. 1930 


\section{A Queer Household}

In the 1920s, after the deaths of their parents and the marriages of their other siblings, Carlton and Gladys lived together at Mount Olive. Billy Olive, his son Sammy and Sammy's wife Rosie (McLean), and a domestic servant named Jinny also lived on the property. ${ }^{25}$ Carlton had taken over the businesses begun by his father, along with some of his father's public roles such as the Secretary of the Hospital Board, while Gladys ran the household. A keen field naturalist with green fingers, Gladys filled the verandahs of Mount Olive with potted plants, especially orchids (see Figure 8). Gladys had not been brought up to work or to pursue a profession: she, like her sisters, was expected to marry a man of means. Her lack of professional or vocational training, however, was to create economic problems that eventually affected her ability to pursue her long same-sex relationship.

In about 1928, a young schoolteacher named Nell Ferguson was posted to Cooktown, and boarded at Mount Olive. Nell and Gladys became romantic friends, presumably lovers, and for about five years shared the Olive family home with Carlton. The conventionally domestic dimension of their shared life is suggested by an early gift from Nell to Gladys of a cookbook published by the Women's Missionary Association of the Presbyterian Church of New South Wales. (At some later date, probably in Ayr, Nell gave Gladys a Rolex Oyster watch — a significant gift which might represent a symbol of commitment.) ${ }^{26}$ Billy, Sammy and Rosie Olive, Jinny and an Aboriginal man known as Chookie also figure prominently in stories and photographs of the era. ${ }^{27}$ As well as contributing in various ways to the domestic economy, the various members of the household shared outdoor activities such as fishing, swimming, boating in dinghies and outrigger canoes, and picnicking (see Figures 9 to 13). The conjugal family of E.A.C. and Grace Olive was replaced by a non-heteronormative family unit that provided a supportive framework for its various members, including the Aboriginal people, who were able to avoid the real threat of removal to a reserve.

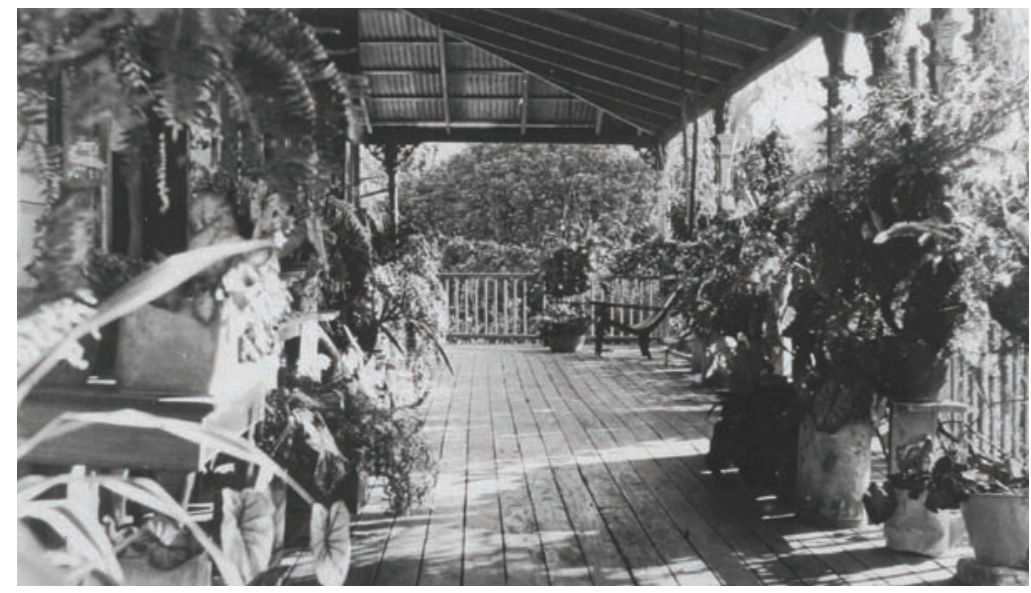

Figure 8: The verandah of Mt Olive, with Gladys Olive's plants, c. 1930 
Carlton and Gladys's nephew, Neil Hope (1919-98) — a future member of Sydney's gay community - recalled being introduced to Nell for the first time in about 1928, at the age of eight or nine, when she and Gladys came to the harbour to meet the boat from Mossman:

it was very hard to get a teacher of quality to stay in Cooktown because it was a run-down place. There would only have been a hundred people there at that stage. And Nell stayed there for five years. Mainly I suppose because of Gladys.

Neil, who remained close to the couple throughout their lives, referred to them specifically as having a 'lesbian relationship', although the women would probably not themselves have used this term. Like others who knew the two women, Neil implied that they were a 'butch-femme' couple: Gladys, he said, was 'a very masculine woman' and Nell a 'most charming woman'.

\section{Moving in from the Margins: Gladys and Nell's Story}

Nell's transfer to Jarvisfield State School in her hometown of Ayr in about 1933 presented the couple with a dilemma. Lack of economic resources, and lack of legal or social acknowledgment of their relationship, constrained their possibilities. As an old man, Neil Hope recalled that he was recruited by Nell to console Gladys:

in about 1933, or '32 maybe, Nell was transferred back to Ayr ... she came to see us [in Mossman] on the way through and she asked me if I would go and stay with Gladys, because she thought Gladys would be lonely and upset. Not that I would be much consolation as a young boy I suppose. But I went to stay there in my Christmas holidays, and stayed with her, oh about two or three weeks I suppose. And that was a great time because I was extremely fond of Gladys. To me she was absolutely great. And she used to take me out shooting and walking and she was a great shot. She had a small raft and she took me out. She used to shoot Torres Strait pigeons, two or three, and we'd have pigeon pie for dinner, which was lovely. But not many women could use a rifle the way Gladys could. And then after a few months, it was arranged that Gladys would go and stay in Ayr ...

For Neil, this holiday with Gladys and Carlton was a crucial formative experience, one he linked in retrospect to the evolution of his identity as a gay man.

In Ayr, Gladys became the housekeeper for Nell and her brother, who owned a cane farm, and this role probably provided Gladys with her only income (see Figure 14). The house had only two bedrooms, so the women shared a room with twin beds - but 'Nell's bed' had the two pairs of slippers lined up against it. ${ }^{28}$ Since Nell had a navy blue car with a dicky seat, the women had some independence. 


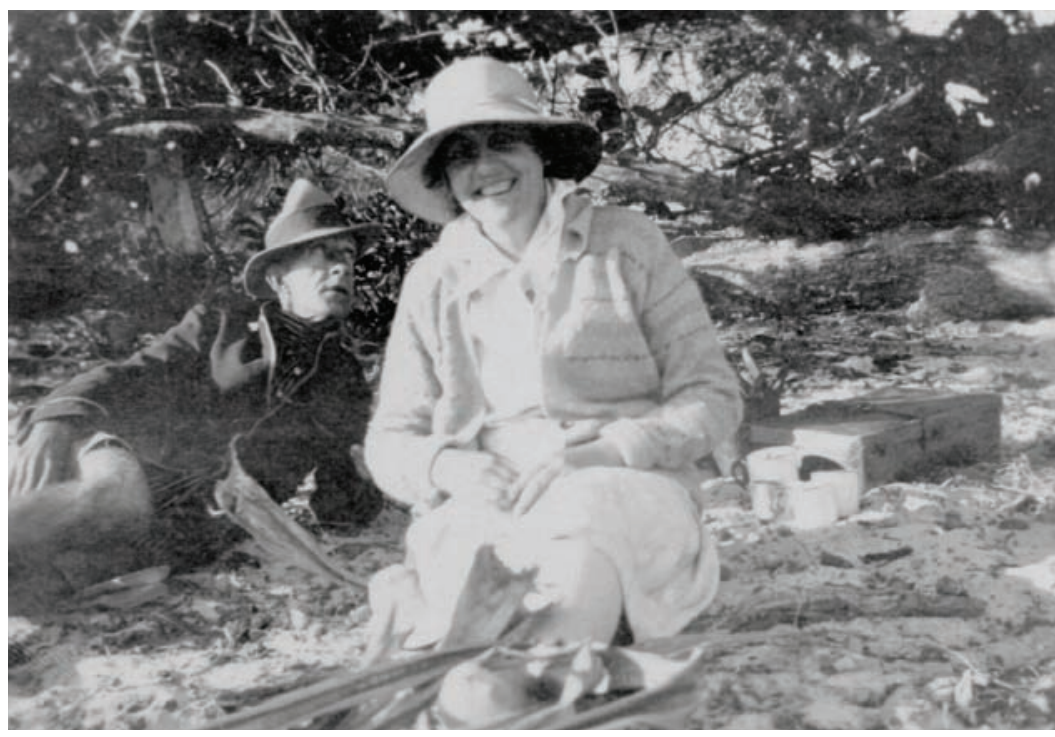

Figure 9: Nell Ferguson and Carlton Olive, Cooktown, c. 1928

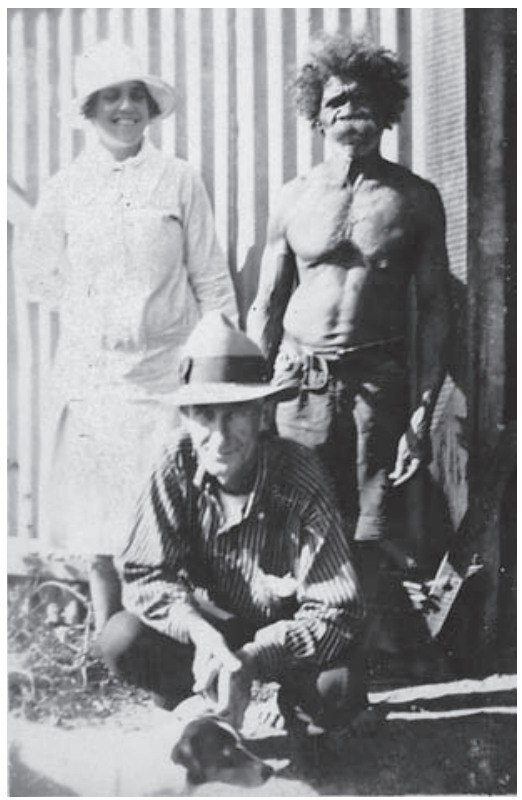

Figure 10: Nell Ferguson with Billy Olive (top right) and Carlton Olive, Cooktown c. 1928. Nell laughs as fox terrier 'Mary Pickford' (named after the movie star) walks into the shot. 


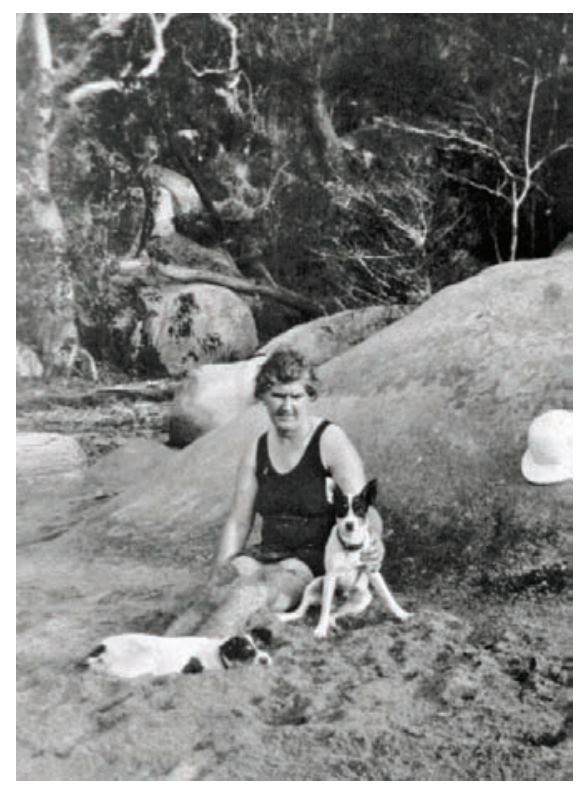

Figure 11: Gladys Olive at the beach with the fox terriers, Cooktown, c. 1930

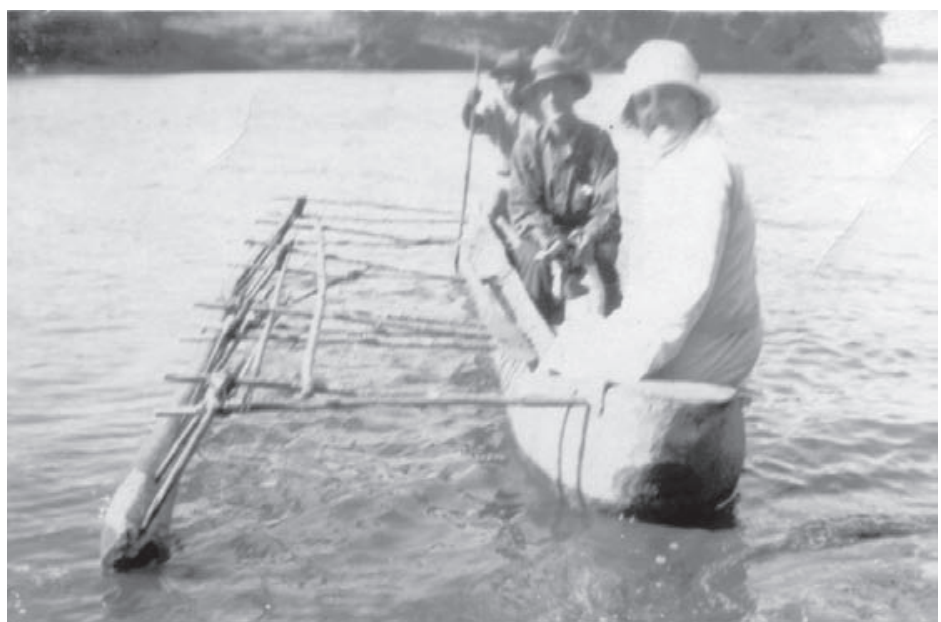

Figure 12: Nell Ferguson, with Carlton Olive (centre) and an unidentified man in a dug-out canoe with outrigger, c. 1928 
Gladys liked to go fishing, but she also entered cakes, jams and flowers in the agricultural show, and tended a beautiful rose garden. Gladys's young great-nieces, Beverley and Elizabeth Allan - future lesbians, and (like Neil Hope) perceptive informants for this project - moved to Ayr in 1938 and became close to the two women, who were extremely devoted and indulgent aunts (see Figure 15). Some surviving letters from this period reveal that Nell took on the rather 'wifely' role of writing to other family members on behalf of herself and Gladys.

In Ayr, Gladys's more 'mannish' and Nell's more 'feminine' style of selfpresentation were somewhat undercut by the fact that Nell had a job outside the family, while Gladys worked in the domestic sphere. After leaving Cooktown, Gladys dressed in a more socially conforming way, choosing to wear dresses rather than trousers. However, the tie she wears in Figure 16 may represent a discreet code to suggest her sense of herself as more 'mannish' than feminine. ${ }^{29}$ In photographs, both Gladys and Nell wear 'sensible' clothes and may even - in contrast to the perception of some observers - have attempted to dress alike rather than as 'butch' and 'femme'. Gladys's modification of her dress strongly suggests that she was exercising a strategic form of self-surveillance (conforming to Ayr's prevailing social codes, more rigid than Cooktown's) - in order not to arouse suspicion about the nature of her relationship with Nell, but also that she was able to dissociate dress from a sense of intrinsic identity.

In the early 1940s, several factors compelled Gladys and Nell to move to Brisbane: Nell's brother married and claimed the room shared by Gladys and Nell; North Queensland was evacuated in expectation of imminent invasion by the Japanese; and Nell, who was probably already ill with cancer, was transferred to the Correspondence School in Brisbane (apparently with her salary - already less than a man's - further reduced). In Brisbane, Gladys had no income and was conscripted by Manpower, and spent the war working first at Hargrave's cannery near Lota and then as a cook at the United Services Club. Later, she worked for timber millers Hancock and Gore. ${ }^{30}$ Lack of financial resources and the move to a city overcrowded with evacuees from North Queensland as well as Australian and American troops meant that Gladys and Nell were no longer able to live together. Gladys moved in with her sister Grace's family at Manly on Moreton Bay, while Nell too boarded with family friends at Sherwood - quite a distance away and on a different train line. They spent weekends together in Gladys's room at Manly (see Figure 17). In the late 1940s, Beverley Allan, who was then a medical student, heard a family conversation about Gladys and Nell, which included the words, 'and they sleep together like husband and wife'. ${ }^{31}$ She recalled that Gladys at this time wore tailored dresses and a masculine felt hat, while Nell was more floral, but that the relationship seemed to be very equal. When Nell was in St Helen's Hospital, Gladys visited her every day, and was devastated by her death in about 1950. ${ }^{32}$ Gladys lived at Manly until her own death on 13 August 1965.

For this couple, ironically, the move from the margins to the city represented not a liberation, but an erosion of self-determination and an apparent increase (at 


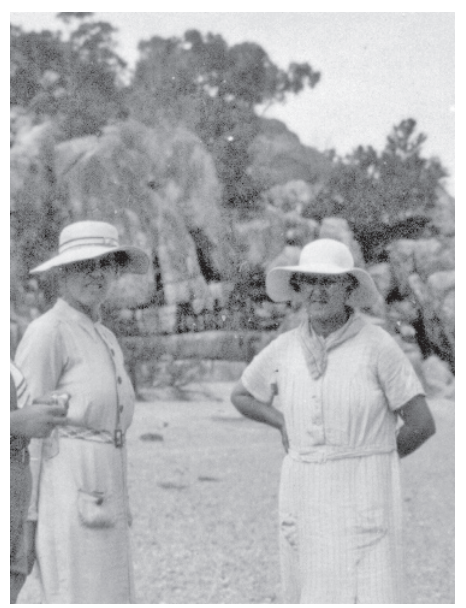

Figure 13: Nell Ferguson (L) and Gladys Olive, Cooktown, early 1930s

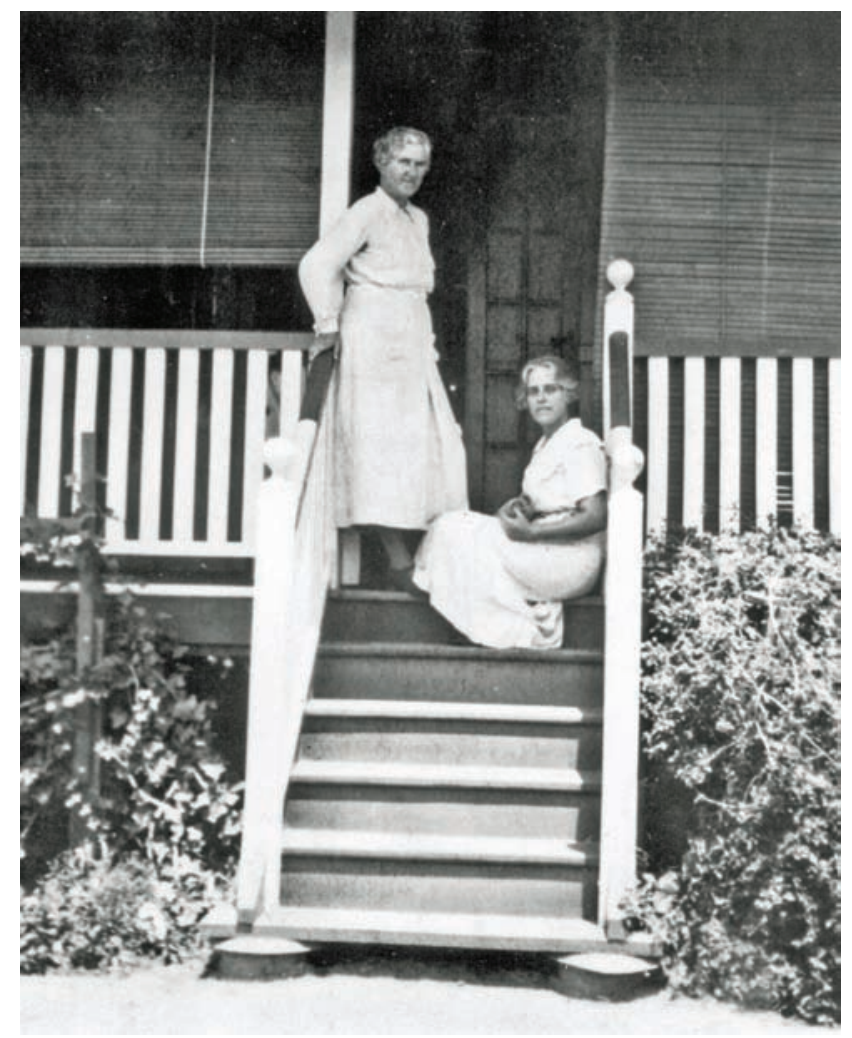

Figure 14: Gladys Olive and Nell Ferguson, Ayr, c. 1940 
least for Gladys) of self-surveillance. In Cooktown, their unconventional relationship was lived out in an unusually fluid domestic space: non-heteronormative, multiethnic, and relatively opaque to external scrutiny. In Ayr, they found themselves in a heteronormative environment that required self-surveillance and their domestic life was eventually displaced through Nell's brother's marriage. In Brisbane, they were separated and able to live together only on weekends.

Were Gladys and Nell a 'lesbian couple'? Perhaps not, if we think of 'lesbian' as an identity. They were, however, at the very least (to borrow Judith M. Bennett's cautious but suggestive term) 'lesbian-like' in their commitment to each other. ${ }^{33}$ They were also 'lesbian-like' in their experience of having their relationship rendered invisible or not real: there must have been deep pain in the weekly separation in Brisbane because of the economic impossibility of forming a household together. Like lesbians in Australia today, Gladys had no legal rights to be with Nell when she was in hospital or to make arrangements after she died. Within the wider society, Gladys faced what Judith Butler has termed the 'de-realization' ${ }^{34}$ of the significance of her relationship with Nell, although within the family there was partial acknowledgment of them as a couple with a marriage-like relationship.

\section{Living on the Margins: Carlton's Story}

When Gladys and Nell left Cooktown, Carlton remained, making occasional trips to Cairns to visit family (see Figure 18). During World War II, the house at Mount Olive was occupied by American servicemen, and in 1948 it was so badly damaged by a cyclone that it had to be demolished. Carlton lived his final years in his shop next door to the Commercial Hotel (now the Cooktown Hotel). Travel writer Barbara Toy recorded that he 'came each day to eat at the hotel, wandering in and out at will. No one, I felt, ever thought of charging him for his meals.' Bob Cook, an Englishman who came to Cooktown in the late 1940s, remembered Carlton as being very quiet, and the business as being virtually non-existent at that low point in the town's history: 'He was the auctioneer — or said he was. ${ }^{\text {, }}$ Cooktown's permanent population, already in decline, reached its lowest point during the war years when those not essential to the war effort were evacuated and the town was largely taken over by American and Australian soldiers.

Carlton's most important work in his later years was a labour of love: he became the unofficial caretaker of the Chinese temple (or Joss House, as it was known), having been requested to look after it by the last Chinese to leave Cooktown. In the early 1980s, an elderly Rene Hallam told journalist Duncan Jackson:

Mr Olive salvaged all the abandoned Joss House. There were no Chinese left in the town. He spent many hours gilding and repainting the carvings and the Gods ... He had a very comprehensive collection and all visitors to Cooktown made it a point to view his Museum. ${ }^{36}$ 


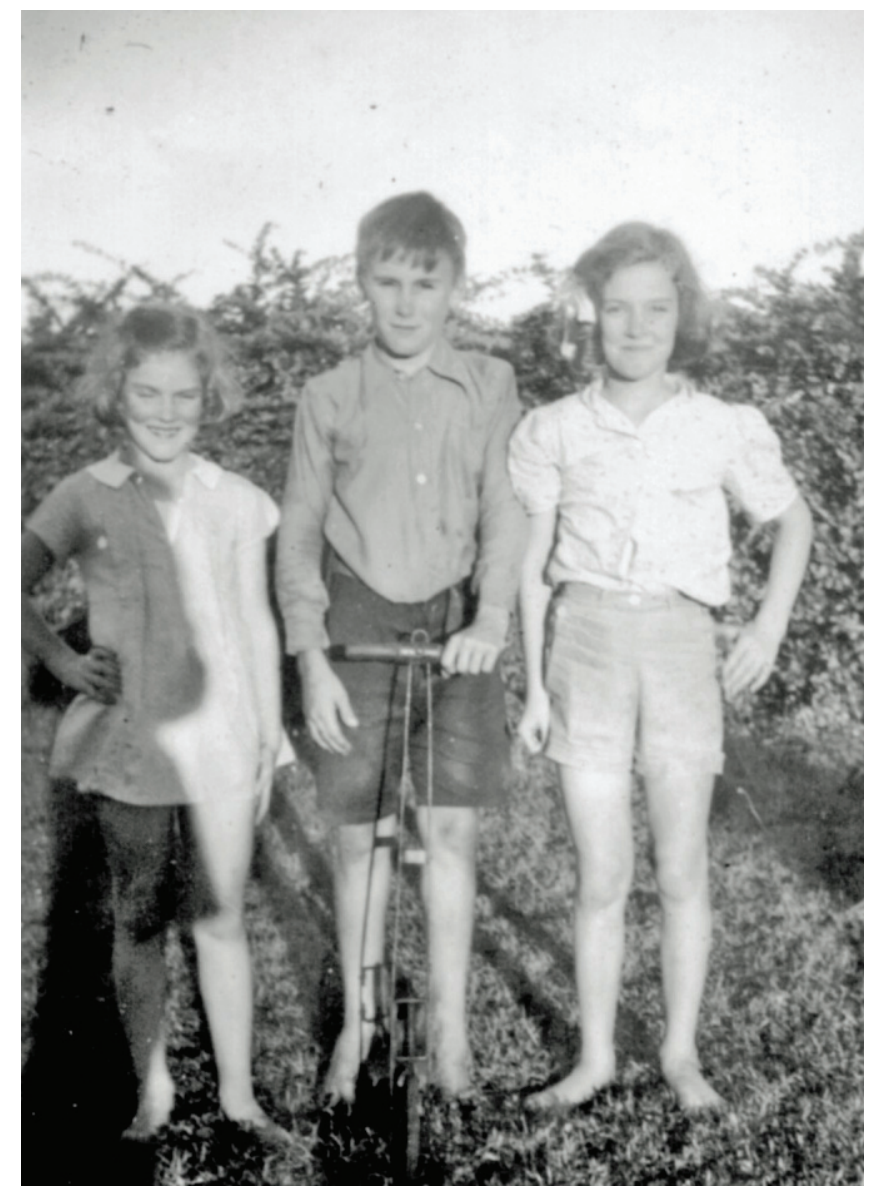

Figure 15: Elizabeth Allan (L) and Beverley Allan (R) with Nell's nephew Malcolm in Ayr, c. 1940

Barbara Toy was one such visitor, and left a record of her encounter with Carlton and his treasures in her book Columbus Was Right! Rover Around the World:

Next door to the Commercial Hotel was a small shed owned by Mr. Olive. Over the door was an old sign with the word 'auctioneer' just discernible. In the garden at the back were several old pieces of Chinese pottery and a large bronze bell similar to those I had seen in Thailand and Malaya ... Later we went into the shed. There were Chinese statues, screens, plaques, and pictures. They were mixed up with an odd collection of bric-à-brac. He was particularly fond of a large panel of carving in which the centre piece was a heavily gilded rising sun.

'It is very sensible to worship the sun,' he said suddenly: 'One is always sure that it will rise. What else is there to be sure of in this world?' 


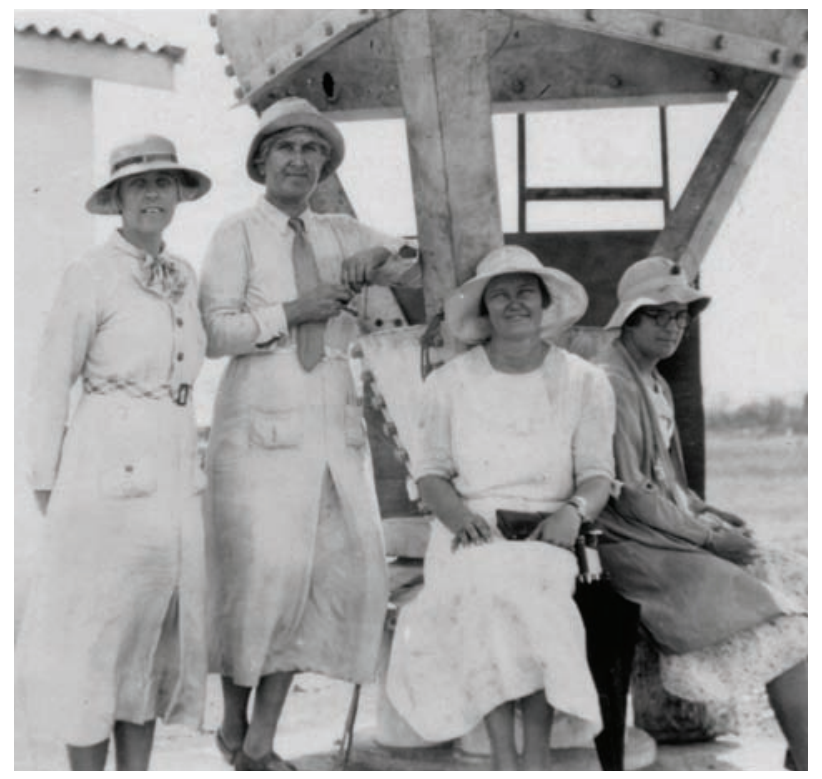

Figure 16: From left, Nell Ferguson and Gladys Olive with friends at Clevedon, south of Townsville, 1935

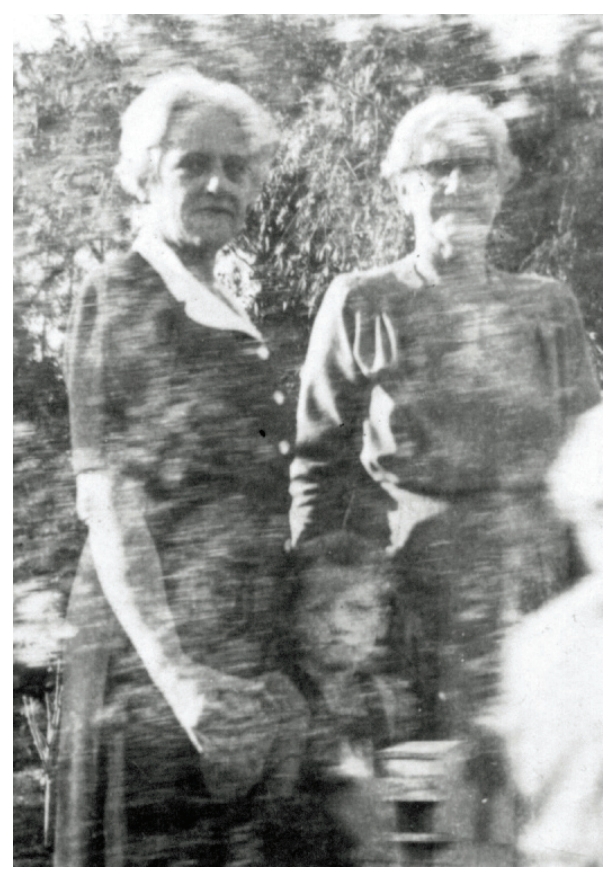

Figure 17: Nell Ferguson (L) and Gladys Olive at Manly in the late 1940s. Nell holds the hand of Gladys's great-niece, Charmaine, of whom the women were very fond. The evanescence of the photographic image ironically mirrors their 'de-realization' as a couple. 


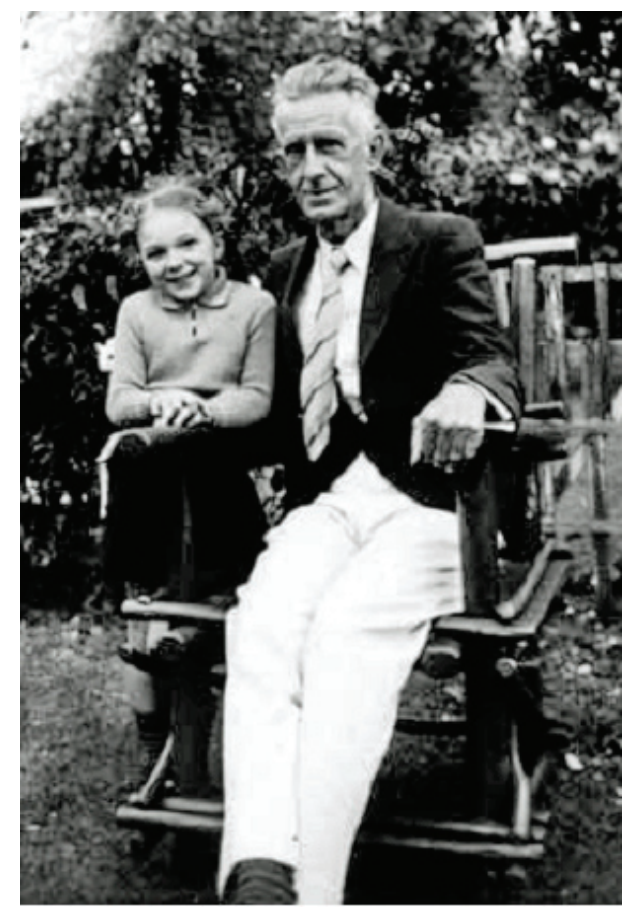

Figure 18: Carlton with his great-niece Ann in Cairns, c. 1940

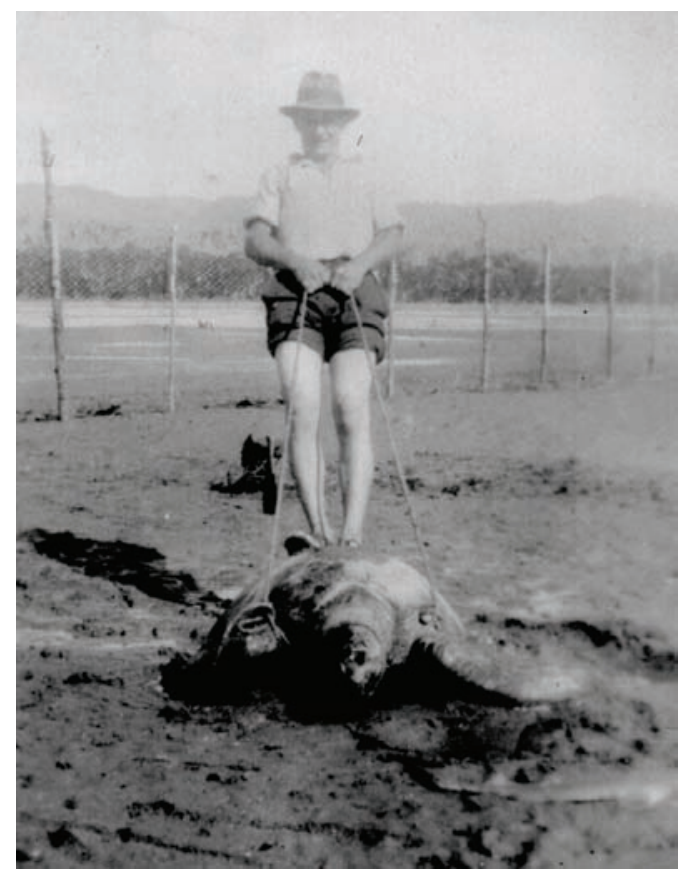

Figure 19: Neil Hope riding a dead turtle on the beach near Mossman, c. 1940 
I picked up a tiny soapstone head. 'Do you sell these?' I asked.

He looked mildly shocked. 'Oh no, I cannot sell them,' he said softly, 'I took them from the Joss House. I am keeping them, they may return.' ${ }^{3}$

Rene Hallam recalled that, on account of Carlton's 'very sudden death' — which left his shop unattended and open to pilferers - some of the items were lost. ${ }^{38}$ Today, the partially reconstructed Chinese temple can be seen in the James Cook Historical Museum, although curiously there is no recognition of Carlton Olive's role in preserving some of the original items.

Carlton's sexual orientation towards men was certainly known among his siblings and their descendants. One of my relatives recalled that, at the time of his death (from complications of pulmonary tuberculosis on 31 July 1958), Carlton was facing criminal charges over his relations with a young man, but I have not found a record of any actual charges. In interviews, elderly Cooktown residents hint at Carlton's homosexuality but refuse to be explicit. Carlton and his younger brother Herbert Lawrence 'Bertie' Olive both lived in Cooktown into old age, but there was hostility between them. When I was conducting interviews some years ago, long-time residents of Cooktown divided into two camps: pro-Carlton or pro-Bertie. Those who were pro-Carlton called him by his family nickname of 'Bando'. For example, the late Bob Cook - who spoke highly of 'Bando' - reported that there was bad blood between the brothers because Bertie 'did not hold with [Bando's] way of living'. ${ }^{39}$ Local amateur historian and long-time resident Nancy Keable, a friend of Bertie and his wife, told me that Carlton's niece, Grace Worrall, refused to mix with him. When pressed as to the reason, she responded only that 'Carlton had his own way of living', but refused to be drawn on the precise nature of that 'way of living'. ${ }^{40}$ Neil Hope certainly referred to his uncle as 'gay', but unfortunately I never asked him what precisely he knew about Carlton's sexual life or sense of identity.

While he may have been ostracised by some Cooktown residents, even members of his own family, Carlton remained in Cooktown throughout his life and has been described as 'very easy going'. This might suggest that sexuality was regulated in Cooktown more through informal social controls than by legal processes. Carlton may also have been protected by his family's long association with the town, his own role in business and public life, his prowess in 'masculine' activities, and his self-assurance.

\section{The Second Generation: 'Flora'}

Neil Hope, the son of Carlton and Gladys's sister Emma, was born on 8 June 1919 and grew up in Mossman, north of Cairns. Neil was a tall and athletic young man, with something of the willowy, tanned ephebe affect and almost courtly manners of his Uncle Carlton. He was an excellent swimmer, and a photograph from this time shows him riding a dead turtle that had washed up on the beach (see Figure 19). Although his male cousins referred to him as a 'pansy', ${ }^{41}$ Neil 
said that his gay life did not begin until he moved to Sydney during World War II. When he finished an apprenticeship as a fitter and turner, he was conscripted by Manpower to the small arms factory at Lithgow. Later, he was employed as a fitter and turner at the Commonwealth Aircraft Corporation in Mascot. Neil had a series of relationships over his five decades in Sydney, and during his mother's lifetime he shared a home with her and his male lover of the moment. Into old age, he swam and sunbathed regularly with a group of gay friends, cultivated a magnificent cottage garden as well as orchids, and developed a love of Japanese pottery during a long relationship with Peter, who was ethnically Japanese. Neil said that Gary Wotherspoon's 'City of the Plain': History of a Gay Sub-Culture captured his experience of Sydney's gay life of the 1960s, when homosexuality was seen as a threat to Australia's moral order and private parties were raided by the police. ${ }^{42}$

In the gay community, Neil was known as 'Flora' because of his love of gardening. He traced the source of this passion to Gladys Olive, who gave him advice about orchids in particular over the years. Gladys influenced Neil and his gay identity profoundly, and in many ways appears to have been a far more important influence and role model than Carlton. As Richard, Neil's partner at the time he died, put it: 'Neil loved Gladys. ${ }^{33}$ Although Neil had an active gay social life in Sydney, he also enjoyed domesticity. He loved the Sydney Mardi Gras and took heart from the change of attitudes he had witnessed in his lifetime, while hoping for further change. Like Carlton, Neil maintained a lithe, attractive and surprisingly youthful appearance into old age (see Figure 20). He was also very keen for me to write about our queer genealogy, perhaps as a counter to the 'de-realization' that Gladys and Nell in particular had experienced. Neil died in Sydney in 1998, just short of his $79^{\text {th }}$ birthday.

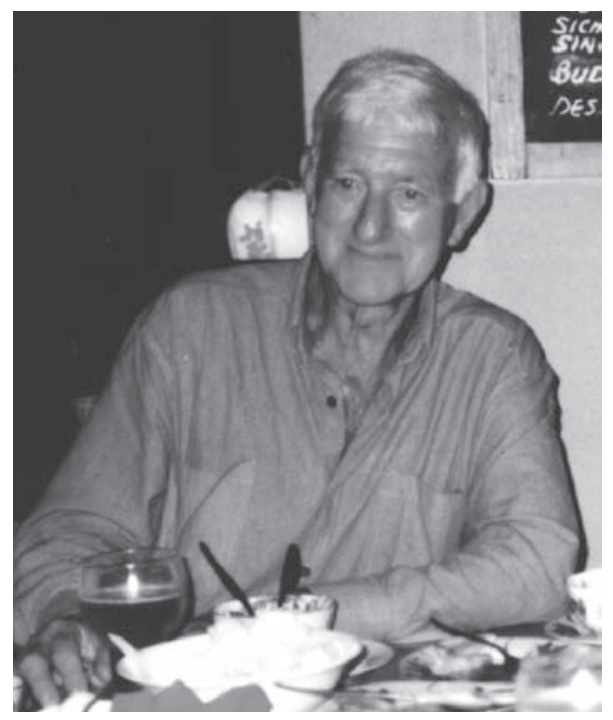

Figure 20: Neil Hope ('Flora'), Sydney, 1992 


\section{The Third and Fourth Generations}

It is rather unusual, even today, to grow up with queer role models within the family. Larry Gross has observed that:

sexual minorities differ from the 'traditional' racial and ethnic minorities; in many ways we are like 'fringe' political or religious groups. We are rarely born into minority communities in which parents or siblings share our minority status. Rather, lesbians and gay men are a self-identified minority, and generally only recognise or announce our status at adolescence. ${ }^{44}$

I never met Carlton, and Nell died before I was born, but I saw a great deal of my elderly great-great-aunt Gladys as a child. She wore trousers and enjoyed physical labour, such as wielding an axe to chop wood or decapitate chooks. I found her role in the domestic landscape of my great-grandparents' home puzzling and once asked her: 'Are you the man of the house?' She responded with peals of laughter — but also, I think, some pleasure that I had recognised the masculinity of her self-presentation. My question betrays the extent to which I had internalised many gender norms at an early age, but the fact that I recall the incident so clearly suggests to me that this was a defining moment in the dismantling of those norms. Nell was dead by then, but 'Auntie Nell' was often mentioned fondly in family conversations, and 'Bando' (Carlton) was often discussed too. Gladys and the later self-identified 'gay' and 'lesbian' relatives revealed to me and other members of my family an alternative to heterosexual norms. I grew up knowing that women could have relationships with other women.

While Gladys and Nell suffered economic hardship, which made it difficult for them to live together, the third generation - Beverley and Elizabeth Allan - had professional careers which rendered them economically independent and able to live openly in long-term lesbian relationships. As a highly qualified physician and medical researcher, Beverley Allan (1931-2004) was able to move relatively easily to the United States when she fell in love with an American woman: her relationship, of course, would have carried no (or negative) weight with US migration authorities, but she was accepted as a skilled migrant. ${ }^{45}$ Beverley lived for many years in the San Francisco Bay area - a major metropolitan centre of queer culture in the late twentieth century and a relatively benign environment for lesbians. Nonetheless, when her partner Nathalie died, Beverley feared that her right to inherit might be tested by a legal challenge. Elizabeth Allan, a physiotherapist, has lived for 34 years with Olga on the north coast of New South Wales, and together they parented Olga's two children from her marriage. Their invention (with no role models) of a non-heteronormative family was an early example of a phenomenon that is much more common today, when many lesbian or gay couples are bringing up children.

For Gladys's great-nieces Beverley and Elizabeth, her relationship with Nell provided an early, tangible model of love between women, and her nephew Neil Hope too explicitly acknowledged the influence of Gladys and Carlton on the 
formation of his own gay identity. In the second and third generations, lesbian and gay identities were adopted explicitly, but there is nonetheless much continuity with the experiences of Gladys and Carlton's generation, and a real sense of affinity. Gladys was an important figure in the first 10 years of my life. I have been close to Beverley (my godmother) and Elizabeth throughout my life, and to Neil later on. As a result, I have always had support within the family, and positive role models. My relationship with my partner Cindy (an American whom I met through Beverley) certainly draws on the lore provided by the same-sex relationships pioneered over the preceding three generations of my family. In a sign of changing times, Cindy was able to migrate to Australia on the basis of our relationship.

\section{Conclusion}

In this paper, using a family case study spanning four generations, I have suggested some ways in which lifestyles developed in outposts of empire, not just in cities, might be implicated in larger patterns of interconnectedness and reciprocity in generating sexual identities. While most previous studies have analysed public records to uncover the history of gay, lesbian or 'queer' culture in Queensland, I have examined private life and domestic space, using oral history, letters and photographs to explore the 'queer' lives of Carlton Olive and his sister Gladys Olive and three subsequent generations of their family. I argue that a particular form of post-Enlightenment Protestant ethic within the family, and the conditions of life in colonial and early twentieth century Cooktown, enabled Carlton Olive, his sister Gladys Olive and her life partner Nell Ferguson to establish an anomalous family unit - non-heteronormative, multi-ethnic and relatively opaque to external scrutiny - in Cooktown in the 1930s. For Gladys and Nell, the move from remote Cooktown to the larger centres of Ayr and then Brisbane represented, ironically, a loss of self-determination in many respects. However, the influence of the lifestyles pioneered by this generation on three subsequent generations of their family demonstrates that modernising forces in the field of sexuality come not only from metropolitan experiences, but also - through reciprocal flows of ideas and people - from experiences developed in response to the conditions of life in remote outposts of empire.

\section{Notes}

1 See, for example, Robert Dixon, Prosthetic Gods: Travel, Representation and Colonial Governance (St Lucia: University of Queensland Press, 2001); Gregory Castle, Postcolonial Discourses: An Anthology (Oxford: Blackwell, 2001); David Punter, Postcolonial Imaginings: Fictions of a New World Order (Edinburgh: Edinburgh University Press, 2000). Clive Moore’s Sunshine and Rainbows: The Development of Gay and Lesbian Culture in Queensland (St Lucia: University of Queensland Press, 2001) is the only major Australian study of gay and lesbian culture with a significant regional focus: it provides ample evidence of the existence of same-sex relationships and behaviours throughout colonial Queensland, and of the development in many Queensland towns of embryonic homosexual subcultures in the twentieth century. 
2 Various forms of nonconformist thought and behaviour which have contributed to the formation of modern personal identities, including sexual identities, originally developed at the geographical, economic and social margins before being transported to the centre. The modernising forces that generated the Protestant Reformation tended to come from the margins of Europe. Later, persecuted groups from Europe established nonconformist Protestantism as the core culture of the United States - the country from which, not coincidentally, the main push for gay and lesbian rights has come. More direct examples of proto-lesbian behaviour and identity which developed on the geographical margins rather in metropolitan centres are provided by the Ladies of Llangollen and Anne Lister.

3 Martha Vicinus, “"They Wonder to Which Sex I Belong”: The Historical Roots of the Modern Lesbian Identity’, Feminist Studies 18(3) (1992): 473.

4 David M. Halperin, Saint Foucault: Towards a Gay Hagiography (New York: Oxford University Press, 1995), 62. See also Alexander Doty, Flaming Classics: Queering the Film Canon (London: Routledge, 2000), 7-8 for a discussion of the various meanings of 'queer/queerness', and the usefulness if 'queer' as a 'suggestive rather than a prescriptive concept'.

5 By 1881, E.A.C. Olive was making repeated reference in business letters to the depressed economy of Cooktown. The Palmer River gold rush, which peaked in 1876, was over by 1886. The 1880s saw massive government investment in Cooktown's infrastructure, but when Aboriginal resistance declined on Cape York Peninsula, government interest in the town waned.

6 See Belinda McKay, 'Constructing a Life on the Northern Frontier: E.A.C. Olive of Cooktown', Queensland Review 7(2) (2000): 47-65.

7 Interview with Neil Hope, Sydney, 25 September 1992. Sammy Olive received an education with the white children.

8 Telephone interview with Guinevere Sacre, 12 August 1992.

9 Having boarded at two public schools - Marlborough then Western College in Brighton - E.A.C. Olive cannot have been unfamiliar with homosexuality. Havelock Ellis in Sexual Inversion attributes the ubiquity of homosexuality in public schools to the fact that the sexual instinct is 'much less specialized' in youth than it later becomes: Havelock Ellis, Sexual Inversion in Studies in the Psychology of Sex, Vol. 1, new edn (New York: Random House, 1936), 75.

10 Ian Watt, The Rise of the Novel: Studies in Defoe, Richardson and Fielding (London: Chatto \& Windus, 2001), 138ff.

11 Janet R. Jakobsen, 'Sex + Freedom = Regulation: Why?', Social Text 23(3-4, 84-85) (2005): 286.

12 Barbara Baird, “'Kerryn and Jackie”: Thinking Historically About Lesbian Marriages', Australian Historical Studies 126 (2005): 270.

13 The available evidence suggests that E.A.C. Olive himself (I have no evidence about his sons) strongly disapproved of the sexual exploitation of Aboriginal women, and did not father any mixed-race children.

14 Interview with Elizabeth Allan, November 2000.

15 Neil Hope, interviewed on 25 September 1992, recalled: '[E]ven when I was there in the '30s you could hear the Aboriginal camp down at the foot of the hill near the salt water corroborreeing every night.'

16 Otto Weininger, Sex and Character, Authorised Translation from the Sixth German Edition (London: William Heinemann, 1907), 45. Weininger's Geschlecht und Charakter was first published in Vienna in May 1903, and the author's suicide at the age of 23 in October 1904 turned the book into a succès de scandale. The sixth edition appeared in December 1904, and was the basis for the anonymous translation into English cited here.

17 Ion L. Idriess, The Tin Scratchers (London: Angus and Robertson, 1980 [1959]), 36.

18 Interview with Guinevere Sacre (daughter of Doris Olive), 7 November 2000.

19 Michel Foucault, The History of Sexuality, Vol. I, trans. Robert Hurley (Harmondsworth: Penguin, 1981), 43. 
20 Hugh David, On Queer Street: A Social History of British Homosexuality 1895-1995 (London: HarperCollins, 1997), between pp. 146 and 147. David interprets the pose as exhibiting 'defiance' in his comment on a photograph of Ian McKellen in a similar pose (opposite p. 147). For copyright reasons I am unable to reproduce these images.

21 Barbara Toy, Columbus Was Right! Rover Around the World (London: John Murray, 1958), p. 191.

22 Ellis, Sexual Inversion, 74, 301, 301n.

23 Clive Moore and Bryan Jamison, ‘Queensland's Criminal Justice System and Homosexuality, 1860-1954', this volume of Queensland Review. See also Yorick Smaal, 'Coding Desire: The Emergence of a Homosexual Subculture in Queensland, 1890-1914', this volume of Queensland Review.

24 Ellis, Sexual Inversion, 300-01.

25 Other Aboriginal people probably lived on the property as well, including a man named Chookie who appears in a number of photos.

26 Interview with Charmaine Phillips, 23 November 2000. Gladys left this watch to her greatniece Charmaine.

27 The photographs are from Gladys Olive's collection, and she appears to have been the photographer: there are many photographs of Nell and others, but fewer of Gladys.

28 Information from Beverley Allan and Elizabeth Allan.

29 Her sister, Grace (Olive) Norbury, also liked to wear trousers. She was once told that it was 'not done' for the wife of a bank manager to wear trousers and go fishing; her reply was: 'Just watch me.'

30 Estelle Runcie Pinney's novel, Time Out for Living (Sydney: Pan Macmillan, 1995), gives a glimpse into the life of women workers in Brisbane during the war from a heterosexual perspective, but the experiences of same-sex attracted women remain largely unexplored.

31 Interview with Beverley Allan, 30 November 2000.

32 Interview with Charmaine Phillips, 20 November 2000.

33 Judith M. Bennett, "Lesbian-Like” and the Social History of Lesbianisms', Journal of the History of Sexuality 9(1-2) (2000): 1-24.

34 Judith Butler, 'Is Kinship Always Already Heterosexual?', differences: A Journal of Feminist Cultural Studies 13(1) (2002): 26.

35 Interview with Bob Cook, 17 July 1995.

36 Duncan Jackson, interview with Rene Hallam, 'An Oral History of Cape York Peninsula', C-168, R-117, 1. See also Toy, Columbus Was Right!, 191.

37 Toy, Columbus Was Right!, 191.

38 Duncan Jackson, interview with Rene Hallam. Hans Looser and Leffie Buhmann, in interviews I conducted with them on 17 July 1995 and 19 July 1995 respectively, reported that they intervened to stop the pilfering of carvings after Carlton Olive's death.

39 Interview with Bob Cook, 17 July 1995.

40 Interview with Nancy Keable, 18 July 1995. Perhaps the lack of acknowledgement of Carlton’s role in preserving the Joss House is related to a taint of scandal at the end of his life.

41 Interview with Beverley Allan, 30 November 2000.

42 Garry Wotherspoon, 'City of the Plain': History of a Gay Sub-Culture (Sydney: Hale \& Iremonger, 1991).

43 Interview with Richard Ash, 21 November 2000.

44 Larry Gross, 'Minorities, Majorities and the Media', in Tamar Liebes and James Curran, eds, Media, Ritual and Identity (London: Routledge, 1998), 90.

45 Having a profession does not nullify discrimination: Beverley Allan believed that in Brisbane her medical career suffered because of her lesbianism, and when her partner Nathalie died, Beverley feared that her right to inherit might be challenged. 